\title{
РЫНОК ЭЛЕКТРОННЫХ ФИНАНСОВЫХ УСЛУГ В РОССИИ: СОВРЕМЕННОЕ СОСТОЯНИЕ, ПРОБЛЕМЫ И ПЕРСПЕКТИВЫ РАЗВИТИЯ
}

\author{
(c) 2019 Левченко Лариса Владимировна \\ кандидат экономических наук, доцент \\ Самарский государственный экономический университет, Россия, Самара \\ E-mail: lvls@mail.ru \\ (c) 2019 Чечёнкова Елена Анатольевна \\ магистрант \\ Самарский государственный экономический университет, Россия, Самара \\ E-mail: chechenkova_ea@mail.ru
}

В настоящем исследовании проводится анализ тенденций совершенствования рынка финансовых услуг в отечественной цифровой экономике. Определены ключевые элементы национального рынка электронных финансовых услуг. Указаны перспективы развития электронных транзакций, осуществляемых с помощью криптовалют. Выделены главные участники рынка электронно-цифровых платежей, определены их функции и их роль в развитии финансового рынка.

Ключевые слова: электронные финансовые услуги, мобильный банкинг, интернет-банкинг, дистанционное обслуживание, блокчейн-технологии.

В современных экономических реалиях электронные финансовые услуги являются наиболее предпочтительным финансовым инструментом осуществления финансовых транзакций в силу высокой скорости проведения платежных операций и отсутствия трансакционных издержек осуществления оплаты заключенных договоров между контрагентами. Проводимое многими банками введение новшеств в свои платежные системы направлено на использование специальных инструментов, повышающих их привлекательность для конечных потребителей финансовых услуг.

Мы можем охарактеризовать электронные финансовые услуги как цифровые, преимущественно банковские, продукты, доступ к которым осуществляется посредством удаленных каналов связи, а именно через банковский сервис клиент-банк, расчетно-кассовое обслуживание юридических лиц, торговля на биржевых площадках посредством установленного соответствующего программного обеспечения.

По мнению ряда авторов, в частности, К.Н. Тимошиной, развитие гаджетов, оказало воздействие на тенденцию, которая связана с передвижением контента и сервисов на мобильные платформы. Некоторые эксперты делают прогноз на то, что число транзакций по всему миру проводимых посредством смартфонов, будет составлять порядка 200 млрд. операций

только за 2020 г [1].

В нашей стране широкое распространение получили дистанционные банковской сервисы, яркими представителями которых являются мобильный банкинг, мобильные операторские платежи, интернет-банкинг. Определенно положительной тенденцией является рост заинтересованности дистанционным банковским обслуживанием (далее - ДБО) физических лиц и корпоративных клиентов.

Наиболее востребованным в настоящее время инструментом ДБО является классический «Банк-Клиент», который работает с помощью установленной на компьютере соответствующей программы, с помощью которой возможно проведение следующего рода финансово-платежных процедур:

- строить платежные задания; оформлять и отправлять в банк клиентское заявление по приобретению или продаже определенной валюты; оформлять, подписывать и отправлять в банк документы по открытию/закрытию банковских счетов;

- отслеживать состояние остатков на расчетных счетах;

- проводить операции с индивидуально-инвестиционными счетами и т.п.

Такой финансовый инструмент как «мобильный банкинг» позволяет в режиме реального времени посредством SMS сообщений прово- 
дить транзакционные операции с контрагентами физическими и юридическими лицами без посещения офиса банка и формирования платежной документации, а также данный инструмент обеспечивает возможность вести аналитику динамики остатка на собственном расчетном счете клиента.

В настоящее время на отечественном финансовом рынке мобильный банкинг занимает существенную долю в электронных платежных системах. Данный финансовый инструмент обладает высокими перспективами развития, в связи с ростом числа потенциальных клиентов, пользующихся мобильными интернет приложениями для осуществления операций расчета.

Банки предоставляют возможность клиентам оплаты товаров и услуг со смартфонов с помощью технологии Near Field Communication, который представляет собой специальный коммуникационный стандарт, служащий для связи между собой компактных устройств на малом расстоянии. Причем модули данной технологии встраиваются и в различные смарткарты, ключи для замков с электронным управлением и альтернативные предметы, лишенные батареи [2].

Следующим, рассмотренным нами финансовым инструментом, являющимся одним из наиболее активно развивающихся элементов электронно-платежных систем, является «мобильный операторский платежный сервис». Он является способом осуществления платежной транзакции посредством дополнения функционала платежного сервиса мобильных операторов (как правило, проводимого посредством смс сообщений) банковского функционала, проявляющееся во взаимосвязи первого с клиентской банковской картой.

В целях повышения числа потенциальных клиентов, пользующихся электронными каналами связи и ДБО, банковским структурам необходимо активнее действовать на рынке электронных финансовых услуг. В современное время наиболее популярными представителями данных направлений в совершении платежных операций являются 5 отечественных банков, «занимающих» более чем 85\% объема проводимых операций в интернете. К таким финансовым структурам можно отнести следующие банковские продукты крупнейших кредитно-финансовых институтов страны:

- Сбербанк-Онлайн,

- Альфа-клик,

- ВТБ-Онлайн,

- Интернет-банкинг банка «Тинькофф»

- Интернет-банкинг банка «Русский Стандарт» [3].

В настоящее время замечен положительная тенденция роста объема электронных транзакций в финансовом секторе отечественной экономике. В России около 35,3 млн. интернет-пользователей в возрасте от 18 до 64 лет пользуются электронными средствами осуществления платежных операций. Ключевыми факторами, способствующими развитию электронных финансовых систем, являются распространение ИКТ в регионах РФ, увеличение числа используемых электронных гаджетов, развитие рынка электронного трейдинга.

Актуальной является технология «Блокчейн», под которой понимается технология цифровых баз данных, использующая в своей основе распределение информации между участниками создания платежной единицы (криптовалюты). Считается, что Блокчейн является достаточно надежным, на данный момент, финансовым инструментом, поскольку в наименьшей степени подвержен внешним корректировкам, изменению первоначально заданных условий контракта [4].

Однако в настоящее время на отечественном рынке электронных финансовых услуг существуют существенные региональные несоответствия, которые объясняются, в первую очередь, возможностями местной инфраструктуры.

Таким образом, для дальнейшего развития российского рынка электронных финансовых услуг необходимо совершенствовать отдельные элементы национальной платежной системы, повышать стабильность проведения электронных транзакций, повышать безопасность электронных операций, усиливать степень доверия потенциальных клиентов к электронным средствам платежа и цифровым финансовым платформам [5].

\section{Библиографический список}

1. Тимошина К.Н. Развитие рынка электронных финансовых услуг в России: современный аспект // Экономические науки. - 2019. - № 3.- С. 96. 
2. Официальный сайт компании i-Free, которая специализируется на создании и внедрении инновационных проектов в области мобильных и NFC-технологий [Электронный ресурс]. - Режим доступа: URL: http://nfcservices.ru(дата обращения 22.11.2019)

3. Богданов М.И. Развитие современного рынка электронных финансовых услуг // Молодой ученый. - 2019.№ $1 .-$ С. 203.

4. Миронова Д.Е. Блокчейн и мировая экономика: азы технологии и основы криптоэкономики // В сб. ст. Междунар. науч.-практ. конф. «Инновационные технологии в науке нового времени» (1 февраля 2019 г., Уфа). Уфа: НИЦ АЭТЕРНА, 2019.- С. 123.

5. Абрамова П.Н. Электронные финансовые услуги в России: проблемы и возможности // Вестник Таганрогского института управления и экономики. - 2018. - № 10.- С. 111. 